\title{
Growth, yield, and oil content of Brassica species under Brazilian tropical conditions
}

\author{
Doglas Bassegio* (D), Maurício Dutra Zanotto (D) \\ Universidade Estadual Paulista “Júlio de Mesquita Filho" - Faculdade de Ciências Agronômicas - Departamento de \\ Melhoramento Vegetal e Agricultura - Botucatu (SP), Brazil.
}

\begin{abstract}
Brassica oilseed species are becoming increasingly popular for industrial uses, with emphasis on biodiesel. It is of importance to evaluate the yield and oil production potential of nontraditional oilseeds for use as feedstock in Brazil. In this study, growth, yield, and oil content and their correlations were determined for eight accessions of $B$. juncea and B. rapa in two years under tropical conditions of southeastern Brazil. Significant variation was observed between $B$. juncea and B. rapa accessions for yield components and oil content. $B$. rapa was the earliest maturing and had the highest oil content, whereas $B$. juncea had the highest number of pods and the highest yield and oil yield. Brassica rapa accessions flowered early, with an average cycle of 97 days, whereas B. juncea reached maturation after 110 days on average. Accessions were grouped according to the oil content of each species, with the most promising accessions having an oil content of $45-47 \%$. Accessions of Brassica species had high oil yields, reaching $910 \mathrm{~kg} \mathrm{ha}^{-1}$ of oil yield for B. juncea PI 180266. There was a linear correlation between oil content and thousand seed weight, pod length, and seeds per pod of the Brassica species accessions. Considering oil content and oil yield across years, Brassica species show promise as alternative oilseed crops for biodiesel production in tropical conditions.
\end{abstract}

Key words: vegetable oils, biodiesel, Brassica, germplasm.
Received:

Oct. 18, 2019

Accepted:

Feb. 3, 2020

Section Editor:

Bruce Topp

${ }^{\star}$ Corresponding author: doglas14@hotmail.com

\section{INTRODUCTION}

The genus Brassica has attracted interest in the industrial and food sectors because it comprises species that are the third-largest source of oil in the world (McVetty and Duncan 2015). Brassica napus is the only Brassica species cultivated in Brazil due to its ability to adapt to tropical conditions. The species is grown in autumn and winter in order to produce high-quality oil in the colder regions of southern Brazil. The cultivation of this species is still insufficient to meet the demand for oil for human consumption.

Due to environmental concerns in recent years and the potential of replacing petroleum-derived fuel sources with renewable products, there has been growing interest in utilizing Brassica species in nonfood applications (Hossain et al. 2019). For large-scale industrial applications, raw materials should compete minimally with food production (Johnson et al. 2007). An example of such competition is canola quality B. napus oil, which if grown for biofuel would compete directly with food-related production (Hossain et al. 2019).

Other oilseed species in the Brassicaceae family, such as B. juncea and B. rapa, have shown potential for biofuel production and other industrial uses in several regions (Hossain et al. 2019). These species generally have a high content (22:1) of erucic acid, which has several industrial applications. Erucic acid has a low flash point, good combustion, and lubricating qualities, all of which makes it a valuable component for biodiesel (Zanetti et al. 2009). Thus, there is great market potential for the expansion and development of new sources of erucic acid, mainly for export (Bhardwaj and Hamama 2000). 
In addition to oil yield, oilseed species must also be able to grow in various environments if they are to be useful for industrial production. In this sense, $B$. juncea can tolerate various types of abiotic and biotic stresses and has been the subject of recent studies in Canada (Gan et al. 2016; Hossain et al. 2019) and in the United States, (Enjalbert et al. 2013; Gesch et al. 2015) as well as in low rainfall areas in India (Kumar et al. 2016) and Australia (Gunasekera et al. 2006a; Wilkes et al. 2013).

The Brassica oilseed species mentioned above have been promising sources of oil (Pavlista et al. 2011; Hossain et al. 2019), but little is known about the cultivation of these oilseeds in Brazil. Thus, a thorough characterization of oil content and oil yield will be useful in identifying new sources of raw material for industrial use in Brazil. Phenotypic variations in yield, flowering, and oil content are essential for the improvement of these species through plant breeding. The hypothesis is that oil content and oil yield vary among Brassica accessions and that these species have the potential for fall-winter cultivation in Brazil. The objective of the study was to determine the growth, yield, and oil content and their correlations for eight accessions of B. juncea and B. rapa in two years under tropical conditions in southeastern Brazil.

\section{MATERIALS AND METHODS}

\section{Site description}

The experiment was conducted in Botucatu, state of São Paulo, Brazil ( $48^{\circ} 25^{\prime}$ W, $22^{\circ} 51^{\prime}$ S, $777 \mathrm{~m}$ above sea level), over a period of two years: 2015 and 2016. The soil was Rhodic Acrudox (Soil Survey Staff 2014). Chemical analysis showed pH 5.1 in $\mathrm{CaCl}_{2}\left(0.01 \mathrm{~mol} \cdot \mathrm{L}^{-1}\right) ; 27 \mathrm{~g} \cdot \mathrm{dm}^{-3}$ organic matter; $34 \mathrm{mg} \cdot \mathrm{dm}^{-3} \mathrm{P}($ Resin- $\mathrm{P}) ; 7 \mathrm{mmol} \cdot \mathrm{dm}^{-3} \mathrm{~K}^{+} ; 48 \mathrm{mmol}_{\mathrm{c}} \cdot \mathrm{dm}^{-3} \mathrm{Ca}^{2+}$; $17 \mathrm{mmol}_{\mathrm{c}} \cdot \mathrm{dm}^{-3} \mathrm{Mg}^{2+} ; 105 \mathrm{mmol} \cdot \mathrm{dm}^{-3}$ of cation exchange capacity (CEC); and $68 \%$ saturation basis. The soil consisted of $630 \mathrm{~g} \cdot \mathrm{kg}^{-1}$ sand, $90 \mathrm{mg} \cdot \mathrm{kg}^{-1}$ silt, and $280 \mathrm{~g} \cdot \mathrm{kg}^{-1}$ clay.

The climate was Cwa, according to the Köppen climate classification system; tropical with dry winters and hot, rainy summers. Long-term (1956-2013) mean annual maximum and minimum temperatures were 26.1 and $15.3^{\circ} \mathrm{C}$, respectively, with a mean annual precipitation of $1358 \mathrm{~mm}$. Precipitation and temperature were measured between May and August during this study (Fig. 1).

\section{Experimental setup}

A randomized complete block design with three replications was applied. Eight accessions of each of B. juncea and B. rapa were evaluated in 2015 and 2016 (Table 1). All Brassica accessions are of industrial type, which is high in erucic acid and glucosinolates. Accessions were obtained from the North Central Regional Plant Introduction Station (NCRPIS-USDA-USA).

Accessions were sown by hand May 8, 2015 and April 27, 2016, in five rows in $3 \mathrm{~m}$ long plots with $0.45 \mathrm{~m}$ spaces between rows. Each plot consisted of 20 plants per square meter. The size of the plot was $6.75 \mathrm{~m}^{2}$. Fertilizer was applied as $30 \mathrm{~kg} \cdot \mathrm{ha}^{-1} \mathrm{~N}$, $84 \mathrm{~kg} \cdot \mathrm{ha}^{-1} \mathrm{P}_{2} \mathrm{O}_{5}$ and $48 \mathrm{~kg} \cdot \mathrm{ha}^{-1} \mathrm{~K}_{2} \mathrm{O}$. Weeds were manually controlled during the cultivation period.

\section{Agronomic measurements}

Flowering time was recorded for each plot as the date when $50 \%$ of the plants had flowered. The cycle was determined by comparing the date of seedling emergence to that of harvest (when $80 \%$ of plants had dry pods) in number of days. Plant height was determined for five randomly selected plants per plot when $50 \%$ of the plants had flowered. Five plants were randomly taken from each plot at full maturity to estimate the seed number per pod and the thousand seed weight. The thousand seed weight was determined by counting subsamples of 100 seeds per plot. The number of seeds per pod and the pod length of each plant were measured across ten pods, taken from the middle part of the terminal raceme. The pod length was measured using a graduated ruler. Yield was estimated by manually harvesting the central useful portion with subsequent threshing, cleaning, and correction to $90 \mathrm{~g} \cdot \mathrm{kg}^{-1}$. Oil content was determined by TD-NMR in an SLK-SG-200 spectrometer (Malagueno, Cordoba, Argentina). Oil yield was calculated as the product of oil content and seed yield. 


\section{Statistical analyses}

Data were evaluated for normality and homogeneity of variances using Kolmogorov-Smirnov and Levene's tests, respectively. The data were evaluated using ANOVA; means were compared using the Scott-Knott test $(\mathrm{p} \leq 0.05)$ and application of simple linear correlation with oil content $(\mathrm{p} \leq 0.05)$. Data was subjected to principal component analysis $(\mathrm{PCA})$ to reduce the number of variables in the original data set to a more significant set of variables, while maintaining maximum information. For this analysis, data from all agronomic traits were standardized, resulting in a mean equal to zero and variance equal to unit. All statistical analyses were performed using Minitab 17 Statistical Software (Minitab Inc., State College, PA).

\section{RESULTS AND DISCUSSION}

\section{Climatic conditions}

Total precipitation during the experiment (May-August) was 268 and $353 \mathrm{~mm}$ in 2015 and 2016, respectively, which is higher than the historical average of $208 \mathrm{~mm}$. However, despite the high average annual rainfall $(1358 \mathrm{~mm})$, precipitation before flowering in 2015 was only $63 \mathrm{~mm}$, distributed almost exclusively within 30 days of its emergence (Fig. 1). In contrast, in 2016, more than $70 \%$ of the annual precipitation occurred prior to the flowering stage, which resulted in higher vegetative growth. However, there was no precipitation in July 2016 and only $80 \mathrm{~mm}$ of rainfall in August 2016. July is historically the driest month $(37 \mathrm{~mm})$, followed by August $(38 \mathrm{~mm})$. Maximum and minimum daily temperatures were similar in both years, although lower temperatures occurred in 2016 during the early stages of growth, falling as low as $2{ }^{\circ} \mathrm{C}$. Higher temperatures $\left(30^{\circ} \mathrm{C}\right.$ ) were observed in 2016 during the flowering stage (Fig. 1).

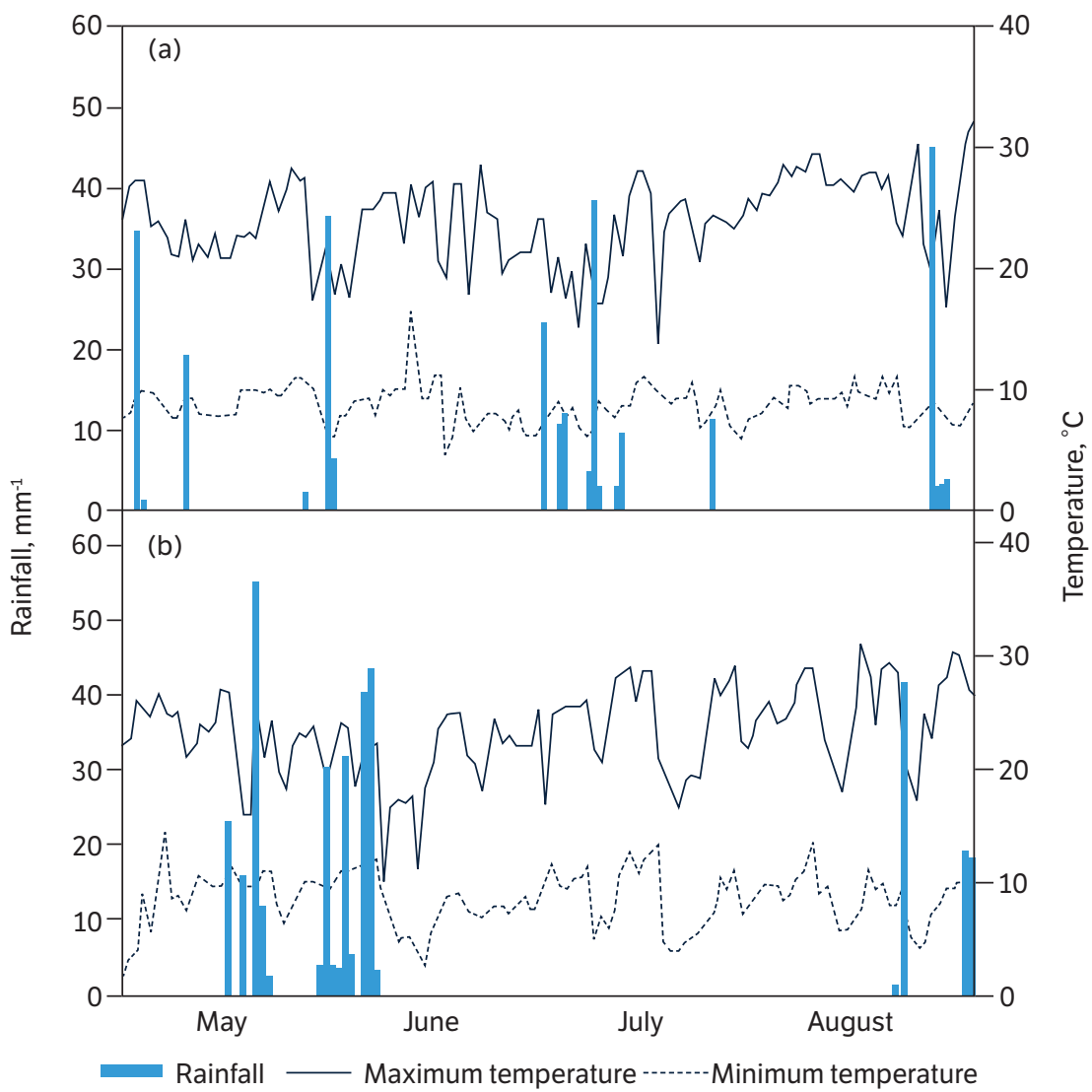

Figure 1. Rainfall, minimum temperature and maximum daily temperature between May and August of 2015 (a) and 2016 (b). 
Table 1. Description of the Brassica species accession used in 2015 and 2016.

\begin{tabular}{|c|c|c|}
\hline Brassica species accessions & Plant name & Origin \\
\hline \multicolumn{3}{|c|}{ Brassica juncea } \\
\hline PI 432386 & BAU $M / 23$ & Bangladesh \\
\hline PI 432384 & BAU M/19 & Bangladesh \\
\hline PI 180266 & - & India, Gujarat \\
\hline PI 449438 & - & Pakistan \\
\hline PI 649105 & IB 391 & India \\
\hline PI 426394 & K 759 & Pakistan \\
\hline PI 180421 & - & India, Rajasthan \\
\hline PI 432379 & BAU M/9 & Bangladesh \\
\hline \multicolumn{3}{|c|}{ Brassica rapa } \\
\hline PI 6841 & Sampad & Bangladesh \\
\hline PI 6838 & Tori 7 & Bangladesh \\
\hline PI 603026 & K 656 & Pakistan \\
\hline PI 6839 & Kalyania & Bangladesh \\
\hline PI 352789 & Sarson & India \\
\hline PI 432373 & BAU M/39 & Bangladesh \\
\hline PI 340199 & IB 115 & India \\
\hline PI 347597 & $\mathrm{BCb} 9$ & India \\
\hline
\end{tabular}

All Brassica species accessions are of industrial type, which is high in erucic acid and glucosinolates.

\section{Yield components}

On average, the accessions of $B$. juncea and B. rapa flowered in 52 and 39 days, respectively. The range was 39 to 66 days for B. juncea and 31 to 56 days for B. rapa (Tables 2 and 3). A similar average was observed by Enjalbert et al. (2013) in a study of 94 accessions in Colorado, USA, under irrigation (52 days) and dryland conditions (50 days). The accessions of $B$. rapa had early flowering in tropical conditions. Padilla et al. (2005) were also able to group accessions of $B$. rapa by early flowering (44 days) in the northwest region of Spain. Khan et al. (2013) observed an interval of 30 to 36 days for full flowering of the accessions in Bangladesh.

On average, B. juncea reached maturation after 112 days and B. rapa after 70 days. The range was 77 to 122 days for B. juncea and 88 to 112 days for B. rapa (Tables 2 and 3). Gesch et al. (2015), when comparing species of oilseeds sown in May in Minnesota, USA, reported 97 to 113 days between planting and harvest, with a short crop cycle for $B$. rapa, which tended to have a lower yield due to early maturation, as observed in the present study. The access of B. juncea PI 426394 included one of the latest cycles in 2015 and the latest cycle in 2016 (122 days). This cycle should not be a problem in the regions of Brazil, as corn and wheat that are grown in winter have similar or longer cycles.

In the $B$. juncea accessions plant height was higher by $12 \%$, on average. This species is characterized by vigorous growth, which is why it is used as a cover crop. The range was 59 to $155 \mathrm{~cm}$ for $B$. juncea and 49 to $130 \mathrm{~cm}$ for B. rapa (Tables 2 and 3). Similar results were observed by Chauhan et al. (2007) $(158$ to $179 \mathrm{~cm})$ for $B$. juncea. On average, the accessions of $B$. juncea and B. rapa reached a height of 109 and $97 \mathrm{~cm}$, respectively (Tables 2 and 3), which was substantially lower than the values reported by Iqbal et al. (2008) (> $200 \mathrm{~cm})$ but higher than those observed by Enjalbert et al. $(2013)(65 \mathrm{~cm})$. There was a slight increase of $8 \%$ for B. juncea and 7\% for B. rapa in 2016 compared to 2015, respectively. This demonstrates uniform plant growth. Thus, the physical characteristics of the analyzed accessions are in agreement with the literature and the results indicate that 
Table 2. Flowering, cycle, height, pods, pod length (PL), seeds per pod, thousand seed weight (TSW), oil content, yield and oil yield of Brassica species in 2015.

\begin{tabular}{|c|c|c|c|c|c|c|c|c|c|c|}
\hline Species & $\begin{array}{c}\text { Flowering } \\
\text { (days) }\end{array}$ & $\begin{array}{l}\text { Cycle } \\
\text { (days) }\end{array}$ & $\begin{array}{l}\text { Height } \\
(\mathrm{cm})\end{array}$ & Pods & $\begin{array}{l}\mathrm{PL} \\
(\mathrm{cm})\end{array}$ & $\begin{array}{l}\text { Seeds } \\
\text { per pod }\end{array}$ & $\begin{array}{l}\text { TSW } \\
\text { (g) }\end{array}$ & $\begin{array}{c}\text { Oil } \\
\text { content } \\
(\%)\end{array}$ & $\begin{array}{c}\text { Yield } \\
\left(\mathrm{kg}^{\prime} \mathrm{ha}^{-1}\right)\end{array}$ & $\begin{array}{l}\text { Oil yield } \\
\left(\mathrm{kg} \cdot \mathrm{ha}^{-1}\right)\end{array}$ \\
\hline \multicolumn{11}{|c|}{ Brassica juncea } \\
\hline PI 432386 & $51 a$ & $103 b$ & $106 a$ & $231 b$ & $3.3 \mathrm{e}$ & $13.5 \mathrm{c}$ & $2.2 \mathrm{~d}$ & $42.2 \mathrm{~b}$ & 1017 a & $430 \mathrm{a}$ \\
\hline PI 432384 & $39 c$ & $104 \mathrm{~b}$ & $82 c$ & $331 a$ & $3.1 \mathrm{e}$ & $9.9 c$ & $1.7 \mathrm{~d}$ & $37.7 c$ & $1123 a$ & $423 a$ \\
\hline PI 180266 & $48 \mathrm{~b}$ & $104 \mathrm{~b}$ & $110 \mathrm{a}$ & $228 b$ & $3.8 \mathrm{~d}$ & $13.4 \mathrm{c}$ & $3.1 \mathrm{c}$ & $44.2 \mathrm{a}$ & $1108 \mathrm{a}$ & $490 \mathrm{a}$ \\
\hline PI 449438 & $51 a$ & $108 a$ & $121 \mathrm{a}$ & $168 c$ & $3.8 \mathrm{~d}$ & $10.6 c$ & $2.4 \mathrm{~d}$ & $44.3 \mathrm{a}$ & $743 b$ & $328 \mathrm{~b}$ \\
\hline PI 649105 & $47 \mathrm{~b}$ & $104 b$ & $97 \mathrm{~b}$ & $304 a$ & $3.5 \mathrm{e}$ & $11.9 \mathrm{c}$ & $2.1 \mathrm{~d}$ & $41.5 \mathrm{~b}$ & $1093 a$ & $452 \mathrm{a}$ \\
\hline PI 426394 & $46 \mathrm{~b}$ & $110 \mathrm{a}$ & $115 a$ & $279 a$ & $3.7 \mathrm{~d}$ & $12.3 \mathrm{c}$ & $2.4 \mathrm{~d}$ & $44.0 \mathrm{a}$ & $1060 \mathrm{a}$ & $466 a$ \\
\hline PI 180421 & $49 \mathrm{~b}$ & $107 a$ & $120 \mathrm{a}$ & $183 c$ & $3.9 \mathrm{~d}$ & $11.5 \mathrm{c}$ & $3.0 \mathrm{c}$ & $42.2 \mathrm{~b}$ & $838 b$ & $354 b$ \\
\hline PI 432379 & $41 \mathrm{c}$ & $97 c$ & $83 c$ & $284 a$ & $3.3 \mathrm{e}$ & $12.2 \mathrm{c}$ & $2.2 \mathrm{~d}$ & $41.1 \mathrm{~b}$ & $987 a$ & $404 a$ \\
\hline \multicolumn{11}{|c|}{ Brassica rapa } \\
\hline PI 6841 & $36 d$ & $88 \mathrm{e}$ & $69 \mathrm{~d}$ & $70 d$ & $5.5 b$ & $24.8 \mathrm{a}$ & $7.3 a$ & $44.8 \mathrm{a}$ & $686 b$ & $311 b$ \\
\hline PI 6838 & $33 \mathrm{e}$ & $88 \mathrm{e}$ & $53 \mathrm{e}$ & $164 c$ & $4.5 \mathrm{c}$ & $18.5 b$ & $4.2 \mathrm{~b}$ & $40.8 \mathrm{~b}$ & $625 b$ & $253 b$ \\
\hline PI 603026 & $48 \mathrm{~b}$ & $104 b$ & $109 a$ & $251 b$ & $3.4 \mathrm{e}$ & $13.0 \mathrm{c}$ & $3.0 \mathrm{c}$ & $42.2 \mathrm{~b}$ & $1123 a$ & $475 a$ \\
\hline PI 6839 & $31 \mathrm{e}$ & $88 \mathrm{e}$ & $52 \mathrm{e}$ & $161 c$ & $5.3 b$ & $18.9 \mathrm{~b}$ & $3.9 \mathrm{~b}$ & $43.7 \mathrm{a}$ & $799 \mathrm{~b}$ & $348 b$ \\
\hline PI 352789 & $42 c$ & $97 c$ & $72 \mathrm{~d}$ & $67 d$ & $6.3 a$ & $25.6 a$ & $7.8 \mathrm{a}$ & $44.3 \mathrm{a}$ & $661 b$ & $292 b$ \\
\hline PI 432373 & $37 d$ & $92 \mathrm{~d}$ & $72 \mathrm{~d}$ & $190 \mathrm{c}$ & $5.6 \mathrm{~b}$ & $20.9 b$ & $4.1 b$ & $44.9 \mathrm{a}$ & $668 \mathrm{~b}$ & $300 \mathrm{~b}$ \\
\hline PI 340199 & $42 c$ & $106 a$ & $93 \mathrm{~b}$ & $199 c$ & $4.1 \mathrm{~d}$ & $13.4 \mathrm{c}$ & $3.1 \mathrm{c}$ & $39.3 c$ & $982 \mathrm{a}$ & $388 a$ \\
\hline PI 347597 & $36 \mathrm{~d}$ & $88 \mathrm{e}$ & $71 d$ & $123 d$ & $5.5 \mathrm{~b}$ & $19.9 \mathrm{~b}$ & $3.4 \mathrm{c}$ & $44.4 a$ & $648 b$ & $287 b$ \\
\hline
\end{tabular}

Same letter indicates no difference by Scott-Knott test $(p<0.05)$.

Table 3. Flowering, cycle, height, pods, pod length (PL), seeds per pod, thousand seed weight (TSW), oil content, yield and oil yield of Brassica species in 2016.

\begin{tabular}{|c|c|c|c|c|c|c|c|c|c|c|}
\hline Species & $\begin{array}{c}\text { Flowering } \\
\text { (days) }\end{array}$ & $\begin{array}{l}\text { Cycle } \\
\text { (days) }\end{array}$ & $\begin{array}{l}\text { Height } \\
(\mathrm{cm})\end{array}$ & Pods & $\begin{array}{l}\mathrm{PL} \\
(\mathrm{cm})\end{array}$ & $\begin{array}{c}\text { Seeds } \\
\text { per pod }\end{array}$ & $\begin{array}{l}\text { TSW } \\
\text { (g) }\end{array}$ & $\begin{array}{l}\text { Oil } \\
\text { content } \\
(\%)\end{array}$ & $\begin{array}{c}\text { Yield } \\
\left(\mathbf{k g} \cdot \mathbf{h a}^{-1}\right)\end{array}$ & $\begin{array}{l}\text { Oil yield } \\
\left(\mathrm{kg} \cdot \mathrm{ha}^{-1}\right)\end{array}$ \\
\hline \multicolumn{11}{|c|}{ Brassica juncea } \\
\hline PI 432386 & $57 d$ & $109 \mathrm{~d}$ & $131 b$ & $312 c$ & $3.9 \mathrm{e}$ & $13.5 c$ & $2.9 \mathrm{~d}$ & $42.6 \mathrm{c}$ & $955 \mathrm{e}$ & $406 d$ \\
\hline PI 432384 & $58 c$ & $116 \mathrm{c}$ & $129 \mathrm{~b}$ & 549 a & $3.4 \mathrm{e}$ & $11.5 c$ & $2.2 \mathrm{~d}$ & $37.7 \mathrm{f}$ & $1296 \mathrm{~d}$ & $488 c$ \\
\hline PI 180266 & $61 \mathrm{~b}$ & $115 c$ & $134 b$ & $388 \mathrm{~b}$ & $4.2 \mathrm{~d}$ & $14.8 \mathrm{c}$ & $3.4 \mathrm{~d}$ & $44.2 \mathrm{~b}$ & $2057 a$ & $910 a$ \\
\hline PI 449438 & $66 a$ & $119 b$ & $155 \mathrm{a}$ & $331 c$ & $3.8 \mathrm{e}$ & $11.9 \mathrm{c}$ & $2.7 \mathrm{~d}$ & $42.6 \mathrm{c}$ & $1433 d$ & $611 b$ \\
\hline PI 649105 & $54 \mathrm{e}$ & $109 \mathrm{~d}$ & $93 c$ & $325 c$ & $4.1 \mathrm{~d}$ & $13.0 \mathrm{c}$ & $3.5 \mathrm{~d}$ & $41.1 \mathrm{e}$ & $1586 \mathrm{c}$ & $653 b$ \\
\hline PI 426394 & $56 d$ & $122 \mathrm{a}$ & $131 b$ & $362 b$ & $3.9 \mathrm{e}$ & $13.4 \mathrm{c}$ & $3.1 \mathrm{~d}$ & $43.9 \mathrm{~b}$ & $1612 \mathrm{~b}$ & $707 b$ \\
\hline PI 180421 & $59 c$ & $110 \mathrm{~d}$ & $133 b$ & $239 c$ & $4.4 \mathrm{~d}$ & $12.6 \mathrm{c}$ & $3.1 \mathrm{~d}$ & $41.8 \mathrm{c}$ & $1560 \mathrm{c}$ & $652 \mathrm{~b}$ \\
\hline PI 432379 & $44 \mathrm{f}$ & $106 \mathrm{e}$ & $59 \mathrm{e}$ & $541 a$ & $3.7 \mathrm{e}$ & $12.6 \mathrm{c}$ & $2.9 \mathrm{~d}$ & $43.1 \mathrm{c}$ & $1436 \mathrm{~d}$ & $619 \mathrm{~b}$ \\
\hline \multicolumn{11}{|c|}{ Brassica rapa } \\
\hline PI 6841 & $34 i$ & $92 \mathrm{f}$ & $49 \mathrm{f}$ & $101 \mathrm{~d}$ & $5.6 b$ & $26.1 \mathrm{a}$ & $8.1 b$ & $46.8 \mathrm{a}$ & $1203 d$ & $563 c$ \\
\hline PI 6838 & $34 i$ & $93 \mathrm{f}$ & $41 \mathrm{f}$ & $294 c$ & $4.9 c$ & $18.3 \mathrm{~b}$ & $4.5 c$ & $44.1 \mathrm{~b}$ & $1214 \mathrm{~d}$ & $536 c$ \\
\hline PI 603026 & $56 \mathrm{~d}$ & $112 \mathrm{~d}$ & $130 \mathrm{~b}$ & $377 b$ & $3.7 \mathrm{e}$ & $12.6 \mathrm{c}$ & $3.3 \mathrm{~d}$ & $40.6 \mathrm{e}$ & $1338 d$ & $542 c$ \\
\hline PI 6839 & $35 \mathrm{i}$ & $93 \mathrm{f}$ & $49 \mathrm{f}$ & $303 c$ & $4.9 c$ & $14.3 \mathrm{c}$ & $4.2 c$ & $45.3 \mathrm{~b}$ & $1346 \mathrm{~d}$ & $610 \mathrm{~b}$ \\
\hline PI 352789 & $41 \mathrm{~g}$ & $106 \mathrm{e}$ & $59 \mathrm{e}$ & $119 \mathrm{~d}$ & $6.6 a$ & $27.1 \mathrm{a}$ & $9.6 a$ & $46.9 a$ & $1365 d$ & $641 b$ \\
\hline PI 432373 & $39 \mathrm{~g}$ & $106 \mathrm{e}$ & $73 d$ & $450 \mathrm{~b}$ & $5.6 \mathrm{~b}$ & $20.5 b$ & $2.3 \mathrm{~d}$ & $46.0 \mathrm{a}$ & $871 \mathrm{e}$ & $400 d$ \\
\hline PI 340199 & $43 \mathrm{f}$ & $106 \mathrm{e}$ & $65 \mathrm{e}$ & $356 \mathrm{~b}$ & $4.1 \mathrm{~d}$ & $11.9 \mathrm{c}$ & $3.0 \mathrm{~d}$ & $40.7 \mathrm{e}$ & $1433 d$ & $583 c$ \\
\hline PI 347597 & $38 \mathrm{~h}$ & $93 \mathrm{f}$ & $61 \mathrm{e}$ & $251 \mathrm{c}$ & $5.6 \mathrm{~b}$ & $18.5 \mathrm{~b}$ & $4.7 \mathrm{c}$ & $42.6 \mathrm{c}$ & $1219 \mathrm{~d}$ & $523 c$ \\
\hline
\end{tabular}

Same letter indicates no difference by Scott-Knott test $(p<0.05)$. 
these species can be cultivated in different environments. This is important because the architecture of the plant determines the properties of the primary branches and thus, also the number of pods and consequently the yield of the plant.

The number of pods per plant varied among species and accessions. In the first year, five promising accessions of $B$. juncea were grouped together, containing more than 251 pods per plant (Table 2). Brassica juncea species yielded on average $64 \%$ more pods than B. rapa species, even though the accession PI 603026 (B. rapa) presented 250 pods per plant in 2015 (Table 2). The range of pods per plant was 168 to 549 pods for $B$. juncea and 67 to $450 \mathrm{~cm}$ for $B$. rapa (Tables 2 and 3). The accessions with the smallest number of pods per plant, PI 6841 (70 pods) and PI 352789 (67 pods), belonged to the species B. rapa. In the second year, accession PI 432373 and PI 432384 had more than 500 pods (Table 3). This difference in pod yield per plant from the first to the second year may have occurred mainly due to climatic conditions, including differences in rainfall and temperature. In general, B. juncea accessions had more pods per plant than B. rapa (46\%), which is in accordance with Gunasekera et al. (2006 a).

Pod length and the number of seeds per pod, contrary to the number of pods per plant, were higher in B. rapa accessions, especially in the accessions PI 6841 and PI 352789 (Tables 2 and 3). The range of pod length was 3.9 to $4.4 \mathrm{~cm}$ for $B$. juncea and 3.4 to $6.6 \mathrm{~cm}$ for $B$. rapa, while the range of seeds per pod was 9.9 to $14.8 \mathrm{~cm}$ for $B$. juncea and 13.0 to $27.1 \mathrm{~cm}$ for $B$ rapa (Table 2 and 3). Such accessions had an average pod length of $6 \mathrm{~cm}$ and 26 seeds per pod, whereas the average for the B. rapa species was $5 \mathrm{~cm}$ and 19 seeds per pod (Tables 2 and 3), which is within the interval of seeds per pod (12 to 24) and pod length (4 to $7 \mathrm{~cm}$ ) proposed by Khan et al. (2013). Pods of B. juncea accessions had an average length of $3.6 \mathrm{~cm}$ and 13.5 seeds per pod, which is close to the ranges proposed by Sharma and Sardana (2013) for pod length (4.4 to $6.3 \mathrm{~cm}$ ) and seeds per pods (9.3 to 13.1 seeds) of $B$. juncea cultivated in India. On average over the years, pod length and number of seeds per pod were 36 and 53\% higher in B. rapa in relation to B. juncea, respectively (Tables 2 and 3).

The B. rapa accessions PI 6841 and PI 352789, respectively, had the highest thousand seed weight regardless of growth conditions, with weights ranging from 7 to $9 \mathrm{~g}$ (Tables 2 and 3). The accessions of B. juncea were grouped (Scott-Knott test) according to the smallest thousand seed weight; $2.5 \mathrm{~g}$ on average, in accordance with studies by Enjalbert et al. (2013) (1.09 to $3.20 \mathrm{~g}$ ) and Gunasekera et al. (2006 a) (2.3 to $3.1 \mathrm{~g}$ ). On average over the years, thousand seed weight was $78 \%$ higher in B. rapa species compared to $B$. juncea accessions. The range of thousand seed weight was 1.7 to $3.5 \mathrm{~g}$ for $B$. juncea and 2.3 to $9.6 \mathrm{~g}$ for $B$. rapa (Tables 2 and 3). Seed size is known to be positively correlated with rapid emergence (Enjalbert et al. 2013). Pod characteristics did not vary significantly between the two years and different climatic conditions, indicating that these traits may be largely controlled by genetic variation.

\section{Yield}

Yield of most B. juncea accessions was higher than that of B. rapa in 2015. In the first year, despite irregular rainfall, the yield reached up to $1123 \mathrm{~kg} \cdot \mathrm{ha}^{-1}$ (Table 2), which is close to the average yield for Brassica oilseeds (1200 kg.ha-1) obtained in tropical conditions in India (Kumar et al. 2016) and in the United States (Enjalbert et al. 2013). Yield of B. juncea accessions were on average 29 and 19\% higher than that of B. rapa in 2015 and 2016, respectively (Tables 2 and 3). Gesch et al. (2015) observed that Brassica species with early maturation, such as B. rapa, tend to have a smaller yield than genotypes with later maturation, which supports the findings of this present study.

In 2016, with regular rainfall, especially before flowering, the $B$. juncea accession PI 180266 had a yield of $2057 \mathrm{~kg} \cdot \mathrm{ha}^{-1}$ (Table 3), which is close to the yield documented for the B. juncea accession RBJ-03047 (2222 kg·ha ${ }^{-1}$ ) cultivated in semi-arid conditions in Pakistan (Iqbal et al. 2008) and in the United States (2011 kg $\left.\cdot \mathrm{ha}^{-1}\right)$ (Gesch et al. 2015). The range of yield was 743 to $2057 \mathrm{~kg} \cdot \mathrm{ha}{ }^{-1}$ for B. juncea and 625 to $1433 \mathrm{~kg} \cdot \mathrm{ha}^{-1}$ for B. rapa (Tables 2 and 3). Wilkes et al. (2013) reported variation in yield from 350 to $1640 \mathrm{~kg} \cdot \mathrm{ha}^{-1}$ of $B$. juncea genotypes in Australia. Variation from 30 to $1800 \mathrm{~kg} \cdot \mathrm{ha}^{-1}$ was also observed in Australia by Gunasekera et al. (2006 a), under conditions of late seeding and water scarcity. The accession of $B$. juncea germplasm (PI 180266) is from Gujarat, India, and this accession stood out in both years of the present study in terms of oil yield. Brassica juncea is originally from India and, according to Gan et al. (2007), it is a productive species in semi-arid regions with unreliable rainfall. This increases the potential of the species for cultivation in the dry and warm winter areas of Midwest Brazil. Gunasekera et al. (2006 a, b) reported greater yield stability and short cycle of B. juncea species in dry environments and marginal areas in the south of Western Australia. 
In 2015, there was greater precipitation after flowering and grain filling $(115 \mathrm{~mm})$, which damaged the crop. There is clear evidence that Brassica species are negatively affected by excess soil moisture (Gesch and Cermak 2011). In 2016, over $70 \%$ of annual rainfall occurred before flowering, which resulted in higher vegetative growth and did not affect the crop cycle. These results indicate that regions with high precipitation in winter (July), as is the case of southern Brazil, may have problems with the cultivation of some Brassica species.

The yield obtained for Brassica accessions in the present study is interesting, since the medium-low yield of B. napus species in Brazil is $1500 \mathrm{~kg} \cdot \mathrm{ha}^{-1}$ (Silva et al. 2017). Improved efforts are needed to increase the yield of Brassica species that have high erucic acid content. The yield increase of Brassica industrial crops in Brazil may be more effective due to the rusticity characteristics of the species and lower sensitivity to the environment. These Brassica species are generally more suited to stressful environments associated with low rainfall, high temperatures, and late sowing (Gunasekera et al. 2006 b).

\section{Oil content and oil yield}

Accessions of both species were grouped according to oil content, with the most promising accessions having an oil content of $45-46 \%$. The range of oil content was 37.7 to $44.3 \%$ for B. juncea and 39.3 to $46.9 \%$ for B. rapa (Tables 2 and 3). Despite these similar values, the environment, seeding date and temperature play a key role in seed oil content (Gunasekera et al. 2006 b; Pavlista et al. 2011). Such variation in seed oil content in both Brassica species demonstrates a potential for improvement with future research and corroborates the conclusions of Iqbal et al. (2008). These accessions can be used for a breeding program to begin to increase oil content.

On average, $B$. rapa accessions showed 3\% higher oil content than that of B. juncea species, reaching $46.9 \%$ for B. rapa accessions PI 352789 (Tables 2 and 3). This result was similar to that of Gesch et al. (2015), who found the oil content to be between 44-48\%. However, some accession had a low oil content in both years, such as PI 432384 (37.7\%). Slight variation in oil content over the two years for both species was observed. Less than $2 \%$ variation on average was observed for oil content in both years for both species. Gunasekera et al. (2006 b) reported that oil content varied from 32-45\% in Brassica species. In view of the end use of these oils, the positive characteristics are high erucic acid content and good oxidation stability, the latter evaluated by limited amounts of polyunsaturated fatty acids (PUFA) (Erhan et al. 2006). One of the most important attributes of industrial oilseeds is oil content, and it is important to note that large-scale production of raw materials will depend on yield, which will result in oil yield per hectare. However, it is also the case that large-scale commercial production will depend heavily on profitable markets for seed by-product after oil extraction (Gesch et al. 2015).

In 2015, oil yield ranged from 253 to $490 \mathrm{~kg} \cdot \mathrm{ha}^{-1}$, and in 2016 from 400 to $910 \mathrm{~kg} \cdot \mathrm{ha}^{-1}$ (Tables 2 and 3). Even though $B$. juncea species had a higher yield, the higher average oil content of $B$. rapa accessions reduced the average difference between the species from $26 \%$ in yield to just $14 \%$ in oil yield, demonstrating the value of accessions with high oil content. Gesch et al. (2015) reported variation from 287 to $1588 \mathrm{~kg} \cdot \mathrm{ha}^{-1}$ and 210 to $885 \mathrm{~kg} \cdot \mathrm{ha}^{-1}$ for several Brassica species cultivated in the northern central region of the United States over two years, respectively. This study demonstrated the diversity of yield components responses among different Brassica oilseed species when grown in tropical conditions of southeastern Brazil.

Further studies are needed to determine the causes of these differences to make traditional winter crops in Brazil. The study resulted in the identification of characteristics that will benefit future breeding efforts to further improve genotypes that have shown greater potential for biodiesel and industrial use.

\section{Principal component analysis and correlation}

Principal component biplot demonstrates the correlation between traits average yield components (Fig. 2). In the principal component analysis, the first two PCs accounted for $78 \%$ of the variation. Most of B. juncea accessions were separated in the right-side quadrants of the biplot as they produced more pods, yield, oil yield, height, cycle, and flowering and were taller than B. rapa accessions. On the other hand, B. rapa were separated in the left side quadrants of the biplot as they produced heavier seeds, more seeds per pod, pod length, and oil than B. juncea. Variables associated with yield and oil yield are situated on the right of PC2 in both years (Fig. 2). 


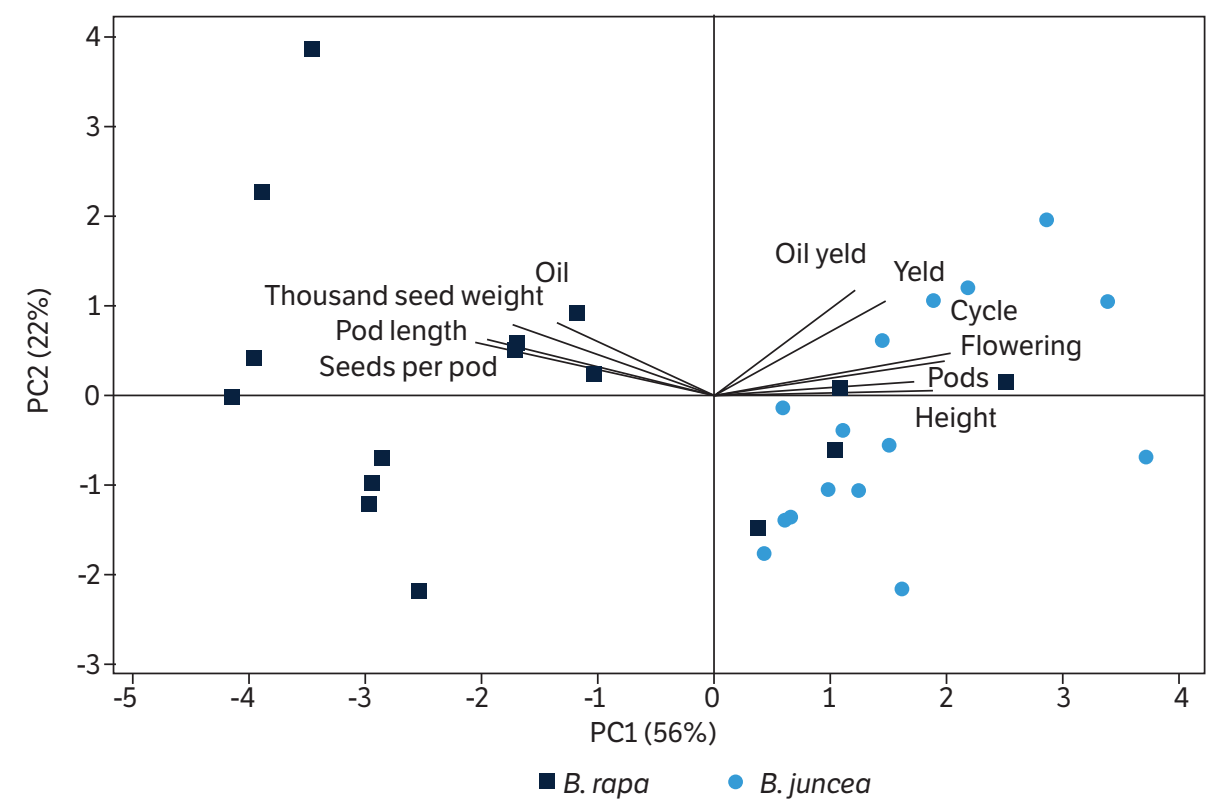

Figure 2. Biplot with the projection of the characteristics in the first two main components with the discrimination of Brassica species in 2015 and 2016.
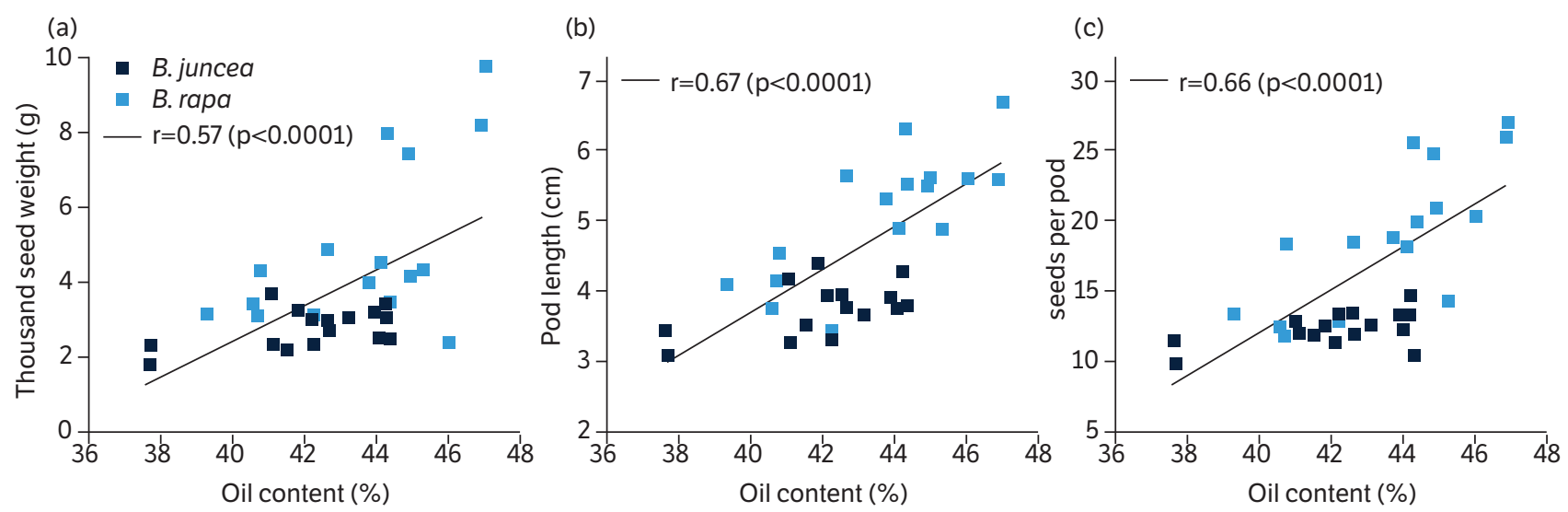

Figure 3. Simple linear correlation of oil content with thousand seed weight (a), pod length (b) and seeds per pod (c) of Brassica species in 2015 and 2016.

Oil content was significantly correlated with the thousand seed weight $(\mathrm{r}=0.66 ; \mathrm{p}<0.001)$ (Fig. 3a), pod length $(\mathrm{r}=0.67$; $\mathrm{p}<0.001)$ (Fig. 3b) and number of seeds per pod ( $r=0.57 ; \mathrm{p}<0.001)$ (Fig. $3 \mathrm{c}$ ). This means it would be relatively easy to select superior genotypes with high oil content. Currently one of the objectives of the Brassica species breeding program is to increase the oil content (Salisbury et al. 2016). Oil content was positively correlated with seeds per pod (Sing and Chowdhu 1983) and seed weight (Gunasekera et al. 2006b) in B. juncea. Therefore, considering these traits as selection criteria will be advantageous in improving $B$. juncea.

Although these Brassica species show promising performance under other environmental conditions (Enjalbert et al. 2013; Wilkes et al. 2013; Gesch et al. 2015), this success has not yet been widely documented under tropical conditions. Nevertheless, the yield components of the species found in Brazil compared favorably with those documented in the literature. The Brassica species, with their ancient and widespread germplasm, have shown potential for future advances in genetic improvement. 


\section{CONCLUSION}

Accessions of Brassica species cultivated during the two-year study had adequate yield and oil yields, demonstrating that they are promising alternative oilseed crops for the cool seasons in tropical environments. This study revealed that $B$. rapa accessions were short-cycle crops and had a high oil content, whereas B. juncea accessions had a high yield and oil yield. On average $B$. juncea had the highest oil yield due to high yield. The positive correlation of thousand seed weight, pod length and seeds per pod with oil content demonstrates the possibility of developing high-oil industrial oilseeds. Brassica species are promising alternative oilseed crops for cultivation during the cool seasons in tropical conditions.

\section{FUNDING}

Coordenação de Aperfeiçoamento de Pessoal de Nível Superior

[https://doi.org/10.13039/501100002322]

Instituto Matogrossense de Algodão

\section{AUTHOR'S CONTRIBUTION}

Conceptualization, Bassegio D. and Zanotto M. D.; Methodology, Zanotto M. D.; Investigation, Bassegio D. and Zanotto M. D.; Writing - Original Draft, Bassegio D. and Zanotto M. D.; Writing - Review and Editing, Bassegio D. and Zanotto M. D.; Funding Acquisition, Zanotto M. D.; Resources, Zanotto M. D.; Supervision, Zanotto M. D.

\section{REFERENCES}

Bhardwaj, H. L. and Hamama, A. A. (2000). Oil, erucic acid, and glucosinolate contents in winter hardy rapeseed germplasms. Industrial Crops and Products, 12, 33-38. https://doi.org/10.1016/S0926-6690(99)00043-6

Chauhan, J. S., Tyagi, M. K., Kumar, A., Nashaat, N. I., Singh, M., Singh, N. B., Jakhar, M. L. and Welham, S. J. (2007). Drought effects on yield and its components in Indian mustard (Brassica juncea L.). Plant Breeding, 126, 399-402. https://doi.org/10.1111/j.1439-0523.2007.01394.x

Enjalbert, J.-N., Zheng, S., Johnson, J. J., Mullen, J. L., Byrne, P. F. and McKay, J. K. (2013). Brassicaceae germplasm diversity for agronomic and seed quality traits under drought stress. Industrial Crops and Products, 47, 176-185. https://doi.org/10.1016/j.indcrop.2013.02.037

Erhan, S. Z., Sharma, B. K. and Perez, J. M. (2006). Oxidation and low temperature stability of vegetable oil-based lubricants. Industrial Crops and Products, 24, 292-299. https://doi.org/10.1016/j.indcrop.2006.06.008

Gan, Y., Malhi, S. S., Brandt, S., Katepa-Mupondwa, E. and Kutcher, H. R. (2007). Brassica juncea canola in the Northern Great Plains: responses to diverse environments and nitrogen fertilization. Agronomy Journal, 99, 1208-1218. https://doi.org/10.2134/agronj2006.0296

Gan, Y., Blackshawb, R. E., Mayc, W. E., Verad, C. and Johnson, E. N. (2016). Yield stability and seed shattering characteristics of Brassica juncea canola in the Northern Great Plains. Crop Science, 56, 1296-1305. https://doi.org/10.2135/cropsci2015.09.0540

Gesch, R. W., Isbell, T. A., Oblath, E. A., Allen, B. L., Archer, D. W., Brown, J., Hatfield, J. L., Jabro, J. D., Kiniry, J. R., Long, D. S. and Vigil, M. F. (2015). Comparison of several Brassica species in the north central U.S. for potential jet fuel feedstock. Industrial Crops and Products, 75, 2-7. https://doi.org/10.1016/j.indcrop.2015.05.084 
Gesch, R. W. and Cermak, S. C. (2011). Sowing date and tillage effects on fall-seeded camelina in the northern corn belt. Agronomy Journal, 103, 980-987. https://doi.org/10.2134/agronj2010.0485

Gunasekera, C. P., Martin, L. D., Siddique, K. H. M. and Walton, G. H. (2006a). Genotype by environment interactions of Indian mustard (Brassica juncea L.) and canola (B. napus L.) in Mediterranean-type environments: 1. Crop growth and seed yield. European Journal of Agronomy, 25, 1-12. https://doi.org/10.1016/j.eja.2005.08.002

Gunasekera, C. P, Martin, L. D., Siddique, K. H. M. and Walton, G. H. (2006b). Genotype by environment interactions of Indian mustard (Brassica juncea L.) and canola (Brassica napus L.) in Mediterranean-type environments: II. Oil and protein concentrations in seed. European Journal of Agronomy, 25, 13-21. https://doi.org/10.1016/j.eja.2006.02.001

Hossain, Z., Johnson, E. N., Wang, L., Blackshaw, R. E. and Gan, Y. (2019). Comparative analysis of oil and protein content and seed yield of five Brassicaceae oilseeds on the Canadian prairie. Industrial Crops and Products, 136, 77-86. https://doi.org/10.1016/j.indcrop.2019.05.001

Iqbal, M., Akhtar, N., Zafar, S. and Ali, I. (2008). Genotypic responses for yield and seed oil quality of two Brassica species under semiarid environmental conditions. South African Journal of Botany, 74, 567-571. https://doi.org/10.1016/j.sajb.2008.02.003

Johnson, J. M.-F., Franzluebbers, A. J., Weyers, S. L. and Reicosky, D. C. (2007). Agricultural opportunities to mitigate greenhouse gas emissions. Environmental Pollution, 150, 107-124. https://doi.org/10.1016/j.envpol.2007.06.030

Khan, M. H., Bhuiyan, S. R., Rashid, M. H., Ghosh, S. and Paul, S. K. (2013). Variability and heritability analysis in short duration and high yielding Brassica rapa L. Bangladesh Journal of Agricultural Research, 38, 647-657. https://doi.org/10.3329/bjar.v38i4.19020

Kumar, S. N., Aggarwal, P. K., Uttam, K., Surabhi, J., Rani, D. N. S., Chauhan, N. and Saxena, R. (2016). Vulnerability of Indian mustard (Brassica juncea (L.) Czernj. Cosson) to climate variability and future adaptation strategies. Mitigation and Adaptation Strategies for Global Change, 21, 403-420. https://doi.org/10.1007/s11027-014-9606-z

McVetty, P. B. E. and Duncan, R. W. (2015). Canola, rapeseed, and mustard: for biofuels and bioproducts. In: Cruz, V. M. V. and Dierig, D. A. (Eds.). Industrial Crops. Handbook of Plant Breeding, vol. 9. New York: Springer. https://doi.org/10.1007/978-1-4939-1447-0_7

Padilla, G. Cartea, M. E., Rodríguez, V. M. and Ordás, A. (2005). Genetic diversity in a germplasm collection of Brassica rapa subsp rapa L. from northwestern Spain. Euphytica, 145, 171-180. https://doi.org/10.1007/s10681-005-0895-x

Pavlista, A. D., Isbell, T. A., Baltensperger, D. D. and Hergert, G. W. (2011). Planting date and development of spring-seeded irrigated canola, brown mustard and camelina. Industrial Crops and Products, 33, 2, 451-456. https://doi.org/10.1016/j.indcrop.2010.10.029

Salisbury, P. A., Cowling, W. A. and Potter, T. D. (2016). Continuing innovation in Australian canola breeding. Crop and Pasture Science, 67, 266-272. https://doi.org/10.1071/CP15262

Sharma, P. and Sardana, V. (2016). Screening of Indian mustard (Brassica juncea) for thermo tolerance at seedling and terminal stages. Journal of Oilseed Brassica, 4, 61-67.

Silva, L. F. L, Gonçalves, W. M., Maluf, W. R., Resende, L. V., Sarmiento, C. M., Licursi, V. and Moretto, P. (2017). Energy balance of biodiesel production from canola. Ciência Rural, 47, 1-5. https://doi.org/10.1590/0103-8478cr20151084

Soil Survey Staff (2014). Keys to soil taxonomy. 12th ed. Washington: USDA.

Wilkes, M. A., Takei, I., Caldwell, R. A. and Trethowan, R. M. (2013). The effect of genotype and environment on biodiesel quality prepared from Indian mustard (Brassica juncea) grown in Australia. Industrial Crops and Products, 48, 124-132. https://doi.org/10.1016/j. indcrop.2013.04.016

Zanetti, F., Vamerali, T. and Mosca, G. (2009). Yield and oil variability in modern varieties of high-erucic winter oilseed rape (Brassica napus L. var. oleifera) and Ethiopian mustard (Brassica carinata A. Braun) under reduced agricultural inputs. Industrial Crops and Products, 30, 265-270. https://doi.org/10.1016/j.indcrop.2009.05.002 